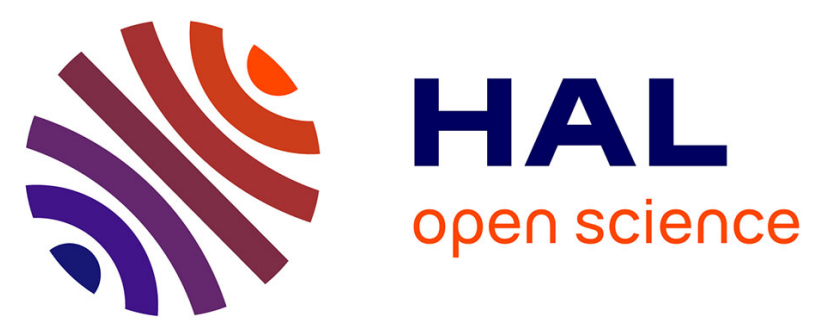

\title{
First Application of the Dakin-West Reaction to Fmoc Chemistry: Synthesis of the ketomethylene tripeptide Fmoc-N $\alpha-\operatorname{Asp}(\mathrm{tBu})-(\mathrm{R}, \mathrm{S}) \mathrm{Tyr}(\mathrm{tBu}) \Psi(\mathrm{CO}-\mathrm{CH} 2) \mathrm{Gly}-\mathrm{OH}$
}

Joseph Richard Casimir, Céline Turetta, Laurent Ettouati, Joëlle Paris

\section{- To cite this version:}

Joseph Richard Casimir, Céline Turetta, Laurent Ettouati, Joëlle Paris. First Application of the Dakin-West Reaction to Fmoc Chemistry: Synthesis of the ketomethylene tripeptide Fmoc$\mathrm{N} \alpha$-Asp(tBu)-(R,S)Tyr(tBu) $\Psi(\mathrm{CO}-\mathrm{CH} 2)$ Gly-OH. Tetrahedron Letters, 1995, 36 (27), pp.4797-4800. 10.1016/0040-4039(95)00869-E . hal-01333228

\section{HAL Id: hal-01333228 \\ https://hal.science/hal-01333228}

Submitted on 17 Jun 2016

HAL is a multi-disciplinary open access archive for the deposit and dissemination of scientific research documents, whether they are published or not. The documents may come from teaching and research institutions in France or abroad, or from public or private research centers.
L'archive ouverte pluridisciplinaire HAL, est destinée au dépôt et à la diffusion de documents scientifiques de niveau recherche, publiés ou non, émanant des établissements d'enseignement et de recherche français ou étrangers, des laboratoires publics ou privés.

\section{(ㅇ)(1) $\$$}

Distributed under a Creative Commons Attribution - NonCommercial - NoDerivatives $\mid 4.0$ 


\title{
First Application of the Dakin-West Reaction to Fmoc Chemistry: Synthesis of the ketomethylene tripeptide Fmoc- $N \alpha-A \operatorname{sp}(t \mathrm{Bu})-(\mathrm{R}, \mathrm{S}) \mathrm{Tyr}(\mathrm{tBu}) \Psi(\mathrm{CO}-\mathrm{CH}) \mathrm{Gly}-\mathrm{OH}$
}

\section{Joseph Richard Casimir, Céline Turetta, Laurent Ettouati* and Joëlle Paris}

\author{
Université Claude Bernard Lyon I, Institut des Sciences Pharmaceutiques et Biologiques, Laboratoire de Chimie Thérapeutique \\ 8 avenue Rockefeller F-69373 Lyon cedex 08
}

\begin{abstract}
A practical synthesis of a tripeptide containing a ketomethylene isostere, suitably protected for introduction in Fmoc SPPS, has been carried out for the first time in Fmoc chemistry by using a modified Dakin-West reaction.
\end{abstract}

In recent years, the use of peptides bearing modified isostere amide bond has been more and more widespread in the study of biological systems as enzymes and receptors. ${ }^{1}$ Among more than dozen different isosteres, the ketomethylene isostere $\Psi(\mathrm{CO}-\mathrm{CH} 2)$ has been widely used to design hydrolytically stable peptides. ${ }^{2}$ Furthemore, and in addition to a higher conformational freedom, this amide bond replacement maintains the H-bond acceptor capacity of the CO group and that property has been used to probe the interaction between receptors and ligands. 3

During our study of Major Histocompatibility Complex (MHC) class II-peptide interactions implicated in immune response, we have used as model the 52-61 peptidic fragment derived from the Hen Egg Lysozyme, HEL(52-61), and synthetized several analogues showing that efficient binding to MHC Class II molecules requires a complex, nonrandom combination of residues with appropriate orientation of the peptide backbone and some crucial side chains. ${ }^{4}$

Recent X-ray studies 5 of a human MHC Class II-peptide complex have shown that hydrogen bonding networks between sidechains of the MHC residues and the amide bonds of the peptide backbone appear to be essential for an optimal binding in addition to one additional anchor residue. So, we planned to replace the Tyr-Gly amide bond of HEL(52-61) by different isosteres and especially ketomethylene one to probe those interactions.

Several synthetic approaches of linear ketomethylene isostere have been described in the literature, e.g. addition of Grignard reagents on aldehydes 6 or activated acids 7 , alkylation of malonic derivatives 8 or use of the Dakin-West reaction. ${ }^{9}$ Among all these strategies, we were looking for an efficient and expeditious method compatible with 9-Fluorenylmethoxycarbonyl (Fmoc)-based Solid Phase Peptide Synthesis (SPPS). In 1985, Mc Murray and Dyckes9b exposed the synthesis of ketomethylene peptidic analogues based on a modification of the Dakin-West reaction by Steglish and Hoefle. ${ }^{10} N \alpha$-Acyl amino acids, dipeptides or tripeptides possessing a free carboxyl function at the $\mathrm{C}$-terminus are heated at $40-50^{\circ} \mathrm{C}$ with triethylamine and 4-dimethylaminopyridine (DMAP) and the appropriate anhydride. A subsequent decarboxylation step then yields carboxy 
terminal $\beta$-ketones. It must be stressed that the chirality of the penultimate $\alpha$-carbon is lost.

Mc Murray and Dyckes stated this strategy would be impracticable with base labile protecting group. However, close study of the literature 11 showed that Fmoc protective group could be compatible with the conditions of Mc Murray and Dyckes reaction. Our strategy to obtain the corresponding Tyr-Gly ketomethylene derivative of HEL(52-61) requires the synthesis of the protected tripeptide Fmoc- $N \alpha$-Asp $(t \mathrm{Bu})-\mathrm{Tyr}(t \mathrm{Bu})-\Psi\left(\mathrm{CO}-\mathrm{CH}_{2}\right) \mathrm{Gly}-\mathrm{OH}$.

First of all, the synthesis of the dipeptide Fmoc- $N \alpha-\operatorname{Asp}(t \mathrm{Bu})-\operatorname{Tyr}(t \mathrm{Bu}) \mathrm{OH} 4^{12}$ has been carried out in solution by coupling of Fmoc- $N \alpha-\mathrm{Asp}(t \mathrm{Bu}) \mathrm{OSu}$ with O-tButyl protected tyrosine with 75\% yield in DMF/DMSO mixture because of poor solubility of tyrosine.

The Dakin-West reaction requires a suitably mono-protected anhydride so as to deprotect then the C-terminus carboxyle for introduction in the HEL(52-61) sequence. Allyl ester would be the best protecting group allowing its selective deprotection by $\operatorname{Pd}(0)$ complex. ${ }^{11}$ In order to obtain the suitably protected anhydride, succinic anhydride $\mathbf{1}$ was opened by allyl alcohol in toluene at reflux with DMAP to give the mono-acid $\mathbf{2}^{13}$ with $90 \%$ yield. Finally, the synthesis of the anhydride $3^{14}$ was carried out by coupling with water soluble coupling agent 1-(3-dimethylaminopropyl)-3-ethylcarbodiimide (EDC), and used immediately for the subsequent Dakin-West reaction.

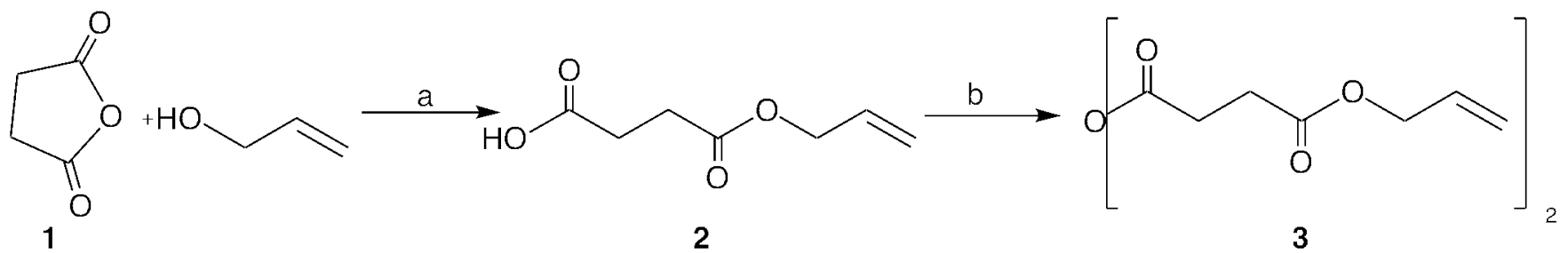

a. DMAP, toluene, reflux, 4h, $90 \%$; b. EDC $0.5 \mathrm{eq}, \mathrm{CH}_{2} \mathrm{Cl}_{2}$, r.t., $3 \mathrm{~h}, 85 \%$.

The Dakin-West reaction between the dipeptide $\mathbf{4}$ and the anhydride $\mathbf{3}$ was performed according to Mc Murray and Dyckes conditions $9 \mathrm{~b}$ except $\mathrm{CH}_{2} \mathrm{Cl}_{2}$ was used as solvent. The ketomethylene $\mathbf{5}^{15}$ was obtained after flash chromatography with good yield.<smiles>C=CCOC(=O)CCC(=O)C(Cc1ccc(OCCC)cc1)NC(=O)C(CC(=O)OCCC)NC(C)C</smiles>

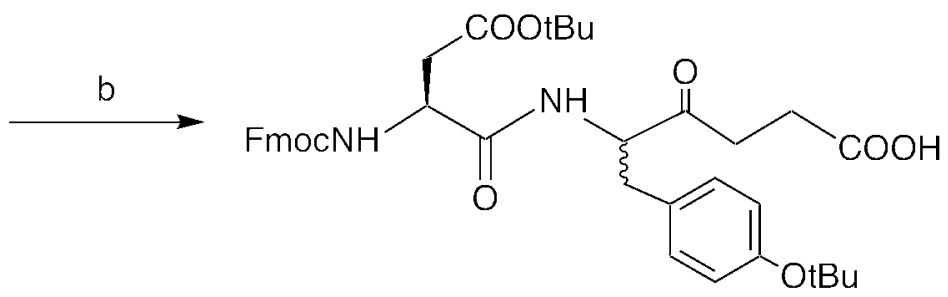

6

a. i) Et3 3 , DMAP cat., $\mathrm{CH}_{2} \mathrm{Cl}_{2}$, reflux, 1 h. ii) removal of solvents in vacuo. iii) $\mathrm{NaHCO}_{3} 5 \%$, r.t., $30 \mathrm{mn}, 74 \%$.

b. $\mathrm{Pd}\left(\mathrm{Ph}_{3}\right)_{4}, \mathrm{CH}_{3}\left(\mathrm{CH}_{2}\right)_{3} \mathrm{CH}\left(\mathrm{C}_{2} \mathrm{H}_{5}\right) \mathrm{COOK}, \mathrm{AcOEt} / \mathrm{CH}_{2} \mathrm{Cl}_{2}$, r.t., 1 h, $71 \%$. 
As expected, $1 \mathrm{H}$ NMR spectrum of the ketomethylene $\mathbf{5} 15$ shows a 50:50 diastereomeric mixture owing to the racemisation of the $\alpha$ tyrosine carbon. 9 b No detectable separation of the two diastereomers has been noted during purification by flash chromatography or control of the purity by HPLC.

Finally, the target molecule $\mathbf{6}^{16}$ was obtained with $71 \%$ yield by treatment of 5 with $\operatorname{Pd}(0)$ complex in presence of potassium 2-ethylhexanoate 17 as scavenger.

In conclusion, we have shown for the first time that Dakin-West reaction could be applied to Fmoc chemistry by synthetizing the ketomethylene tripeptide Fmoc- $N \alpha-\mathrm{Asp}(t \mathrm{Bu})-(\mathrm{R}, \mathrm{S}) \operatorname{Tyr}(t \mathrm{Bu}) \Psi\left(\mathrm{CO}-\mathrm{CH}_{2}\right) \mathrm{Gly}-\mathrm{OH}$ in good overall yield. The incorporation of this compound in the HEL(52-61) sequence and the biological activity of the corresponding ketomethylene peptide will be described in due course.

\section{ACKNOWLEDGEMENTS}

We would like to gratefully acknowledge the "Région Rhône-Alpes" for funding.

\section{REFERENCES AND NOTES}

1. For recent reviews, see: a) Kahn, M. Synlet 1993, 821-826. b) Giannis, A. and Kolter, T. Angew.Chem. Int. Ed. Engl. 1993, 32, 1244-1267. c) Olson, G.L.; Bolin, D.R.; Bonner, M.P.; Bös, M.;Cook, C.M.; Fry, D.C.; Graves, B.J.; Hatada, M.; Hill, D.E.; Kahn, M.; Madison, V.S.; Rusiecki ,V.K.; Sarabu, R.; Sepinwall, J.; Vincent, G.P.; and Voss, M.E. J. Med. Chem 1993, 36 , 3039-3049. d) Gante, J. Angew Chem Int. Ed. Engl. 1994, 33, 1699-1720. d) Liskamp, R.M.J. Recl. Trav. Chim. Pays-Bas 1994, 113, 1-19. e) Adang, A.E.P.; Hermkens, P.H.H.; Linders, J.T.M.; Ottenhijm, H.C.J. and van Staveren, C.J.S. Recl. Trav. Chim. Pays-Bas 1994, 113, 63-78.

2. Almquist, R.G.; Olsen, C.M.; Uyeno, E.T. and Toll, L. J. Med. Chem 1984, 27, 115-120.

3. DiMaio, J.; Gibbs, B.; Lefebvre, J.; Konishi ,Y.; Munn, D. and Yi Shue, S. J.Med. Chem 1992, 35, $3331-3341$.

4. Hernandez, J.-F.; Cretin, F.; Lombard-Platet, S.; Salvi, J.-P.; Walchshofer, N.; Gerlier, D.; Paris ,J.; and Rabourdin-Combe, C. Peptides 1994, 15, 583-590.

5. Stern, L.J.; Brown, J.H.; Jardesky, T.S.; Gorga, J.C.; Urban, R.G.; Strominger, J.L. and Wiley, D.C. Nature 1994, 368, 215221.

6. Holladay, M.W. and H. Rich, D. Tetrahedron Lett. 1983, 41, 4401-4404.

7. a) ref. 2. b) Mansour, T.S. Synth. Comm. 1989, 3\&4, 659-665. c) ref. 3.

8. a) García-López ,M.T.; Gonzaléz-Muñiz, R. and Harto, J.R. Tetrahedron 1988, 44, 5131-5138 .b) K a l t e n b r o n n, J . S .; Hudspeth, J.P.; Lunney, E.A.; Michniewicz, B.M.; Nicolaides, E.D.; Repine, J.T.; Roark, W.H.; Stier, M.A.; Tinney, F.J.; Woo, P.K.W. and Essenburg, A.D. J. Med. Chem. 1990, 33, 838-845.

9. a) For a review see: Buchanan, G.L.Chem. Soc. Rev. 1988, 17, 91-109. b) Mc Murray, J.S. and Dyckes, D.F.J. Org. Chem. 1985, 50, 1112-1115. c) Cheng, L.; Goodwin, C.A.; Schully, M.F.; Kakkar, V.V. and Claeson, G. J. Med. Chem. 1992, 35, 3364-3369.

10. Steglish, W. and Hoefle, G. Chem. Ber. 1969, 102, 883-898. 
Dipeptide 4: amorphous white compound. IR ( $v \mathrm{~cm}-1, \mathrm{KBr}) 3320,2977,1734,1507,1238,1161,759,740 . \mathrm{MS}$ FAB (thioglycerol, positive mode) $653\left(\mathrm{MNa}^{+}\right), 597\left(\mathrm{MNa}^{+}-t \mathrm{Bu}\right), 473\left(\mathrm{MNa}^{+}-\mathrm{Fmoc}\right), 179$ (Fmoc). ${ }^{1} \mathrm{H} \mathrm{NMR}(200 \mathrm{MHz}, \mathrm{CDCl} 3, \delta$ ppm): 7.75 (d, J=7.2Hz, 2H, 2H Fmoc), 7.6 (d, J=7.1Hz, 2H, 2H Fmoc), 7.35 (m, 4H, 4H Fmoc), 7.07 (d, J=7Hz,3H, 2H ar

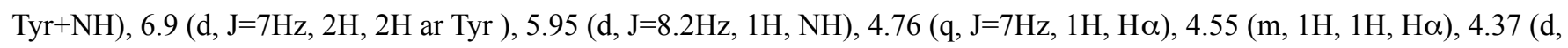
$\mathrm{J}=7.5 \mathrm{~Hz}, 2 \mathrm{H}, 2 \mathrm{H} \mathrm{Fmoc}), 4.2$ (t, J=6.7Hz, 1H, 1H Fmoc), 3.08 (m, 2H, CH2 Asp), 2.8 (m, 1H, CH Tyr), 2.6 (m, 1H, CH Tyr), 142 (s, 9H, tBu Asp), 1.2 (s, 9H, tBu Tyr).

Compound 2: colorless oil. b.p. $108^{\circ} \mathrm{C} / 0.15$ mbar. IR ( $v \mathrm{~cm}^{-1}$, film) 3087, 1735, 1166, 992, 935. MS EI 70eV (m/z): 159 $\left(\mathrm{MH}^{+}\right), 140\left(\mathrm{M}^{+}-\mathrm{H}_{2} \mathrm{O}\right), 101\left(\mathrm{M}^{+}-\mathrm{C}_{3} \mathrm{H}_{5} \mathrm{O}\right) .{ }^{1} \mathrm{H}_{\mathrm{NMR}}(200 \mathrm{MHz}, \mathrm{CDCl} 3, \delta \mathrm{ppm}): 11$ (s, 1H, COOH), 5.93 (m, 1H, H allyl), $5.36(\mathrm{~m}, 1 \mathrm{H}, \mathrm{H}$ allyl), $4.6(2 \mathrm{H}, \mathrm{m}, \mathrm{CH} 2$ allyl), 2.68 (s, 4H, 4H succinic acid ).

Compound 3: colorless oil, IR ( $v \mathrm{~cm}^{-1}$, film) 1823, 1737, 1179, 1052.

15 Experimental procedure: To a solution of $0.56 \mathrm{~g}(0.88 \mathrm{mmol})$ of the dipeptide 4 in $10 \mathrm{ml} \mathrm{CH}_{2} \mathrm{Cl}_{2} \mathrm{was}^{\mathrm{added}} 0.013 \mathrm{~g}$ $(0.106 \mathrm{mmol})$ of DMAP and $0.198 \mathrm{ml}(1.34 \mathrm{mmols})$ of Et3N. The solution was stirred at reflux for one hour at which time the mixture was dried in vacuo. The residue was then stirred for $30 \mathrm{mns}$ at r.t. with $5 \% \mathrm{NaHCO}$, extracted with ethyl acetate and washed with $0.1 \mathrm{~N}$ acetic acid, brine and water. The ethyl acetate solution was dried over $\mathrm{Na} 2 \mathrm{SO} 4$, filtered and evaporated. Finally, the residue was purified by flash chromatography (silica gel, petrol ether/ethyl acetate 8:2 then 5:5) yielding $0.475 \mathrm{~g}$ of 5 as a yellowish oil $(0.65 \mathrm{mmol}, 74 \%$ yield $)$.

Compound 5: yellowish oil. IR ( $v$ cm-1, film) 3321, 2929, 1732, 1507, 1667, 1506, 1367, 1238, 1151, 769, 741. MS FAB ( $m$ NBA, positive mode): $727.9\left(\mathrm{MH}^{+}\right), 671.7\left(\mathrm{MH}^{+}-t \mathrm{Bu}\right), 615.6\left(\mathrm{MH}^{+}-2 t \mathrm{Bu}\right) .1 \mathrm{H} \mathrm{NMR}(200 \mathrm{MHz}, \mathrm{CDCl} 3, \delta \mathrm{ppm}): 7.76(\mathrm{~d}$, $\mathrm{J}=6.9 \mathrm{~Hz}, 2 \mathrm{H}, 2 \mathrm{H} \mathrm{Fmoc}), 7.6$ (d, J=7.15Hz, 2H, 2H Fmoc), 7.35 (m, 4H, 4H Fmoc), 7.1 (m, 1H, NH), 7.03(m, 2H, 2H ar Tyr), 6.8 (m, 2H, 2H ar Tyr ), 5.9 (d, m, 1H, H allyl), 5.3 (m, 1H, H allyl), 5.25 (m, 1H, H allyl), 4.75 (m, 1H, Ho), 4.56 (m, 4H, 4H allyl $+\mathrm{H} \alpha+\mathrm{NH}), 4.38$ (d, J=6.4Hz, 2H, 2H Fmoc), 4.23 (t, J=6.9Hz, 1H, 1H Fmoc), 3.1 to 2.4 (m, 8H, 4H CH2 Asp and CH Tyr; 4H - $\left.\mathrm{CH}_{2} \mathrm{CH}_{2} \mathrm{COO}-\right), 144$ (s, 9H, tBu Asp), 1.29 (s, 9H, tBu Tyr).

Compound 6: colorless oil. IR ( $v \mathrm{~cm}^{-1}$, film) 3329, 2978, 1720, 1672, 1508, 1239, 1161, 759, 741. MS FAB ( $m$ NBA, positive mode): $687.8\left(\mathrm{MH}^{+}\right), 631.7\left(\mathrm{MH}^{+}-t \mathrm{Bu}\right), 575.6\left(\mathrm{MH}^{+}-2 t \mathrm{Bu}\right) .{ }^{1} \mathrm{H} \mathrm{NMR}(200 \mathrm{MHz}, \mathrm{CDCl} 3, \delta \mathrm{ppm}): 7.76(\mathrm{~d}, \mathrm{~J}=7.35 \mathrm{~Hz}, 2 \mathrm{H}, 2 \mathrm{H}$ Fmoc), 7.57 (d, J=6.9Hz, 2H, 2H Fmoc), 7.35 (m, 4H, 4H Fmoc), 7.18 (m, 1H, NH), 7.03(m, 2H, 2H ar Tyr), 6.86 (m, 2H, 2H

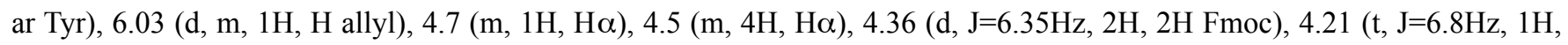
1H Fmoc), 3.05 to 2.4 (m, 8H, 4H CH2 Asp and CH Tyr; 4H - $\left.\mathrm{CH}_{2} \mathrm{CH}_{2} \mathrm{COOH}\right), 142$ (s, 9H, tBu Asp), 1.28 (s, 9H, tBu Tyr). Jeffrey, P.D. and McCombie, S.W. J. Org.Chem., 1982, 47, 587-590. 